\title{
Peculiarities of protective efficiency of nitrogen containing inhibitors of steel corrosion
}

\author{
L. E. Tsygankova, ${ }^{1 *}$ V. I. Vigdorovich, ${ }^{2}$ N. V. Shel ${ }^{2}$ and E. V. Dubinskaya ${ }^{2}$ \\ ${ }^{1}$ Department of Analytical Chemistry, Derzhavin State University, Tambov, \\ 392000 Russian Federation \\ ${ }^{2}$ Department of Chemistry, Tambov State Technical University, Tambov, \\ 392000 Russian Federation \\ *e-mail:vits21@mail.ru
}

\begin{abstract}
The protective efficiency of a number of nitrogen containing inhibitors against steel hydrosulfide corrosion and their effect on the kinetics of partial electrode reactions have been studied by gravimetrical corrosion tests, polarization resistance and impedance spectroscopy methods. The bactericidal efficiency of the inhibitors with respect to sulfate reducing bacteria (SRB) has been estimated as a function of their nature and concentration.
\end{abstract}

Key words: inhibition, corrosion, protective effect, polarization resistance, impedance spectroscopy, bactericidal action.

Received: September 21, 2013.

doi: $\underline{10.17675 / 2305-6894-2013-2-4-304-310}$

\section{Introduction}

The protective efficiency of inhibitors of hydrosulfide and carbon dioxide steel corrosion is generally studied in two model media:

1. Highly mineralized chloride media containing $30-150 \mathrm{~g} / \mathrm{L} \mathrm{NaCl}$ with various concentrations of hydrogen sulfide $(10-1500 \mathrm{mg} / \mathrm{L})$ [1]. As a rule, such model solutions satisfactorily simulate metal corrosion under oil production conditions. Corrosive media containing carbon dioxide are prepared by $\mathrm{CO}_{2}$ introduction to the solutions used in the laboratory studies.

2. The model environment recommended by the National Association of Corrosion Engineers of USA (NACE) contains $5 \mathrm{~g} / \mathrm{L} \mathrm{NaCl}$ and $0.25 \mathrm{~g} / \mathrm{L} \mathrm{CH}_{3} \mathrm{COOH}$ and is saturated with hydrogen sulfide $[2,3]$.

The physicochemical characteristics of these media differ substantially. The acidity of highly mineralized chloride media is small. Their $\mathrm{pH}$ only depends on hydrogen sulfide concentration. This acid is weak: its first and second constants of electrolytic dissociation are $K_{1}=8.9 \cdot 10^{-8}$ and $K_{2}=1.3 \cdot 10^{-13}$. Therefore, the $\mathrm{pH}$ is 5.5-6.0. Chloride ions are surface active with respect to carbon steel, therefore the kinetics of steel active anodic dissolution depends substantially on the anion concentration. 
The NACE medium is characterized by $\mathrm{pH}=3.5-3.6$ because of a much higher electrolytic dissociation constant of $\mathrm{CH}_{3} \mathrm{COOH}\left(K=1.74 \cdot 10^{-5}\right)$. This fact can essentially change the nature and concentration of the protonated form of hydrosulfide corrosion inhibitors that frequently belong to nitrogen containing substances. Moreover, the kinetics of iron ionization is a function of solution $\mathrm{pH}$ and $d \log i_{\mathrm{a}} / d \mathrm{pH} \approx 1$ (where $i_{\mathrm{a}}$ is the anodic current density).

Acetic acid is present in NACE medium mainly in molecular form because its degree of dissociation is $\approx 6 \%$. The surface activity of the acid in molecular form has not been studied sufficiently. Nevertheless, it is impossible to neglect its effect on metal anodic ionization. The rather small concentration of surface active chloride ions in the NACE medium favours the adsorption of acetate-containing species both in molecular and anionic forms.

The aim of this paper is to study the peculiarities of inhibitor efficiency depending on the nature of corrosive media and bactericidal action against SRB.

\section{Experimental}

The following inhibitors were used: I - a 10 mass \% solution of higher aliphatic amines $\mathrm{C}_{10}-\mathrm{C}_{16}$ in a mixture of aprotic solvents; II - a mixture of imidazolines and amidoamines obtained in a reaction of polyethylene polyamine with oleic acid. Highly mineralized chloride media containing $50 \mathrm{~g} / \mathrm{L} \mathrm{NaCl}$ and NACE medium saturated by $\mathrm{H}_{2} \mathrm{~S}$ and $\mathrm{CO}_{2}$ were used as the working solutions.

The protective efficiency of inhibitors against steel corrosion was studied by the following methods: gravimetrical corrosion tests [4], linear polarization resistance, and impedance spectroscopy. The steel had the following composition, mass \%: $\mathrm{C}-0.20 ; \mathrm{Mn}-0.50 ; \mathrm{Si}-$ $0.15 ; \mathrm{P}-0.04 ; \mathrm{Cr}-0.30 ; \mathrm{Ni}-0.20 ; \mathrm{Cu}-0.20, \mathrm{Fe}-$ balance. The protective effect $(Z, \%)$ of an inhibitor is calculated according to the formula:

$$
Z(\%)=10^{2}\left(K_{0}-K_{\mathrm{i}}\right) / K_{0}
$$

where $K_{0}$ and $K_{\mathrm{i}}$ are the corrosion rates in the uninhibited and inhibited solution, respectively.

The linear polarization resistance (LPR) technique was used for instant monitoring of variations in corrosion rates in the inhibited and uninhibited solutions [5]. An "Expert-004" LPR device developed at A.N.Frumkin Institute of Physical Chemistry and Electrochemistry of the Russian Academy of Sciences [6] was used in this study.

Electrochemical impedance spectroscopy measurements (Solartron 1255 Frequency Response Analyzer and 1287 potentiostat) were carried out in the frequency range of $10 \mathrm{kHz}-50 \mathrm{mHz}$. Processing of the results was conducted using ZView 3.0 software [7].

The bactericidal properties of the inhibitors with respect to $\mathrm{SRB}$ were studied in the Postgate medium with the composition, g/L: $\mathrm{NH}_{4} \mathrm{Cl}-1.0 ; \mathrm{K}_{2} \mathrm{HPO}_{4}-0.5 ; \mathrm{MgSO}_{4} \cdot 7 \mathrm{H}_{2} \mathrm{O}-$ $2.0 ; \mathrm{Na}_{2} \mathrm{SO}_{4}-0.5 ; \mathrm{CaCl}_{2}-0.1$; calcium lactate -3.5 , yeast extract -1 [8]. The Luk sulfatereducing bacterium strain used in this study was phylogenetically similar (99\% similarity 
of 16S rRNA genes) to the Desulfomicrobium apsheronum $1105^{T}$ strain isolated from a petroleum reservoir [9]. The experiment duration $(168 \mathrm{~h})$ is determined by the SRB vital cycle [10]. The concentration of biogenic hydrogen sulfide was measured daily (iodometric titration).

\section{Results and discussion}

According to gravimetrical corrosion tests in NACE media containing $10 \mathrm{mg} / \mathrm{L} \mathrm{H}_{2} \mathrm{~S}$, the protective efficiency of inhibitor I $(25 \mathrm{mg} / \mathrm{L})$ is $77 \%$. It increases to 87 or $90 \%$ upon a fiveor tenfold increase in hydrogen sulfide concentration, respectively. A further growth in $\mathrm{H}_{2} \mathrm{~S}$ content to $200 \mathrm{mg} / \mathrm{L}$ does not change the $Z$ value. A $Z$ value of $88-91 \%$ is reached in the entire range of $\mathrm{H}_{2} \mathrm{~S}$ concentrations studied and at an inhibitor concentration of $100 \mathrm{mg} / \mathrm{L}$. Inhibitor II is less efficient at a concentration of $25 \mathrm{mg} / \mathrm{L}$ but shows a protective efficiency equal to that of inhibitor I at a four times higher concentration. In the presence of both $\mathrm{H}_{2} \mathrm{~S}$ and $\mathrm{CO}_{2}(1 \mathrm{~atm}$.) simultaneously, the protective efficiency is smaller by $10 \%$.

In highly mineralized chloride media $(50 \mathrm{~g} / \mathrm{L} \mathrm{NaCl})$, the presence of inhibitor I at $25 \mathrm{mg} / \mathrm{L}$ results in very small protective efficiency or even corrosion stimulation (Table 1). A fourfold growth in the inhibitor concentration nearly does not change the picture. Inhibitor II $(25 \mathrm{mg} / \mathrm{L})$ is more efficient under these conditions at $C_{\mathrm{H} 2 \mathrm{~S}}=10$ and $50 \mathrm{mg} / \mathrm{L}$, but its $Z$ decreases essentially with an increase in $\mathrm{H}_{2} \mathrm{~S}$ concentration to $100-200 \mathrm{mg} / \mathrm{L}$ (Table 1). A fourfold growth in its concentration results in a $Z$ value of $87-90 \%$. Addition of $\mathrm{CO}_{2}\left(1 \mathrm{~atm}\right.$.) together with $\mathrm{H}_{2} \mathrm{~S}$ decreases the efficiency of inhibitor I but nearly does not change the efficiency of inhibitor II.

Table 1. Protective efficiency (Z, \%) of inhibitors I (numerator) and II (denominator) in media containing $50 \mathrm{~g} / \mathrm{L} \mathrm{NaCl}$ and $\mathrm{H}_{2} \mathrm{~S}$.

\begin{tabular}{ccccc}
\hline & \multicolumn{5}{c}{$\boldsymbol{Z}, \boldsymbol{\%}$ at $\boldsymbol{C}_{\mathbf{H} 2 \mathrm{~S}}, \mathbf{m g} / \mathbf{L}$} \\
\cline { 2 - 5 } $\mathbf{C}_{\text {Inh }}, \mathbf{m g} / \mathbf{L}$ & $\mathbf{1 0}$ & $\mathbf{5 0}$ & $\mathbf{1 0 0}$ & $\mathbf{2 0 0}$ \\
\hline 25 & $8 / 85$ & $\mathrm{~S}^{*} / 87$ & $11 / 29$ & $21 / 39$ \\
100 & $21 / 88$ & $61 / 90$ & $\mathrm{~S}^{*} / 87$ & $\mathrm{~S}^{*} / 90$ \\
\hline
\end{tabular}

$*$ S denotes stimulation

The corrosion rate of steel decreases in time in both uninhibited and inhibited solutions, but this decrease is more appreciable in the second case, as shown in [5]. This indicates the protective properties of the film corrosion products formed on the steel surface in uninhibited solutions or a combined effect of the film of corrosion products and inhibitor in inhibited solutions. Measurements of the instantaneous corrosion rate by the LPR method in the uninhibited and inhibited solutions for $24 \mathrm{~h}$ and the method described in [5] permit the calculation of the protective effect of the corrosion product film $\left(Z_{\mathrm{f}}\right)$, the total protective effect $\left(Z_{\text {total }}\right)$ of the corrosion product film and inhibitor, and the inhibitor contribution $\left(Z_{\text {Inh }}\right)$ to the total protective effect. 
At small $\mathrm{H}_{2} \mathrm{~S}$ concentration $(10 \mathrm{mg} / \mathrm{L})$ in NACE medium, $Z_{\mathrm{f}}<<Z_{\text {Inh }}$ and the protective efficiency of the film increases with increasing test duration. However, the $Z_{\text {Inh }}$ value remains practically constant, then it decreases 1.5 -fold (Table 2). This is characteristic of both inhibitors. A qualitatively similar picture is observed with a four times higher inhibitor concentration. Furthermore, the $Z_{\mathrm{f}} / Z_{\text {Inh }}$ ratio increases essentially with a growth in test duration in the presence of the inhibitors $(25$ and $100 \mathrm{mg} / \mathrm{L})$ and decreases with an increase in $\mathrm{H}_{2} \mathrm{~S}$ concentration up to $200 \mathrm{mg} / \mathrm{L}$.

Table 2. Effect of $\mathrm{H}_{2} \mathrm{~S}$ concentration and exposure time of steel specimens in the solution on the contributions of the surface film $\left(Z_{\mathrm{f}}\right)$ and inhibitor I $(25 \mathrm{mg} / \mathrm{L})\left(Z_{\text {Inh }}\right.$ to the total protective effect $\left(Z_{\text {total }}\right)$ (numerator, $Z_{\mathrm{i}}$ values in NACE solution; denominator, $Z_{\mathrm{i}}$ values in the solution with $50 \mathrm{~g} / \mathrm{L} \mathrm{NaCl}$ ).

$Z_{\mathrm{i}}$ at hydrogen sulfide concentration, $\mathrm{mg} / \mathrm{l}$

\begin{tabular}{|c|c|c|c|c|c|c|c|c|c|}
\hline \multirow{2}{*}{$\begin{array}{l}\text { Time from the start } \\
\text { of corrosion, } h\end{array}$} & \multicolumn{3}{|c|}{10} & \multicolumn{3}{|c|}{50} & \multicolumn{3}{|c|}{200} \\
\hline & $Z_{\mathrm{f}}$ & $Z_{\text {Inh }}$ & $Z_{\text {total }}$ & $Z_{\mathrm{f}}$ & $Z_{\text {Inh }}$ & $Z_{\text {total }}$ & $Z_{\mathrm{f}}$ & $Z_{\text {Inh }}$ & $Z_{\text {total }}$ \\
\hline 0.15 & $-6 / 62$ & $2 / 23$ & $56 / 85$ & $2 /-5$ & $70 / 18$ & $72 / 12$ & $-7 / 48$ & $76 / 11$ & $69 / 37$ \\
\hline 1.0 & $1 / 80$ & $63 / 8$ & $64 / 88$ & $10 / 18$ & $69 / 29$ & $79 / 47$ & $-3 / 59$ & $80 / 1$ & $77 / 60$ \\
\hline 2.0 & $3 / 81$ & $63 / 8$ & $66 / 89$ & $14 / 36$ & $66 / 24$ & $80 / 60$ & $11 / 63$ & $68 / 1$ & $79 / 64$ \\
\hline 4.0 & $29 / 87$ & $36 / 4$ & $65 / 91$ & $18 / 69$ & $62 /-4$ & $80 / 65$ & $24 / 66$ & $55 / 10$ & $79 / 76$ \\
\hline 20.0 & $29 / 89$ & $39 / 3$ & $68 / 91$ & $36 / 64$ & $46 / 8$ & $82 / 72$ & $26 / 74$ & $57 / 9$ & $83 / 83$ \\
\hline
\end{tabular}

*The “-” sign denotes stimulation.

A different picture is observed in highly mineralized chloride media $(50 \mathrm{~g} / \mathrm{L} \mathrm{NaCl})$. In the presence of inhibitor $\mathrm{I}$, the $Z_{\mathrm{f}} / Z_{\mathrm{Inh}}$ ratio essentially exceeds 1 . It decreases with an increase in $\mathrm{H}_{2} \mathrm{~S}$ concentration from 10 to $50 \mathrm{mg} / \mathrm{L}$ and then increases again with an increase in $C_{\mathrm{H} 2 \mathrm{~S}}$ to 100 or $200 \mathrm{mg} / \mathrm{L}$ (Table 2). The same results are observed in the presence of inhibitor II.

One can conclude that the regularities of polysulfide film growth on steel surface and inhibitor adsorption in NACE medium and in a highly mineralized chloride medium differ substantially. In the former case in the presence of $10 \mathrm{mg} / \mathrm{L} \mathrm{H}_{2} \mathrm{~S}$, the inhibitor is adsorbed quickly and the film is formed slowly. Then, with a growth in $C_{\mathrm{H} 2 \mathrm{~S}}$ to 50 or $100 \mathrm{mg} / \mathrm{L}$, the film formation is accelerated and the effect of both inhibitors is identical. In the presence of $200 \mathrm{mg} / \mathrm{L} \mathrm{H} \mathrm{H}_{2} \mathrm{~S}$, the film structure evidently changes, inhibitor contribution increases substantially and becomes predominant irrespective of the inhibitor nature.

In highly mineralized chloride media, a film of corrosion products is quickly formed already in the presence of 10 and $50 \mathrm{mg} / \mathrm{L} \mathrm{H}_{2} \mathrm{~S}$ and makes a major contribution to $Z_{\text {total }}$. The inhibitor is adsorbed on the film insignificantly and its contribution to $Z_{\text {total }}$ varies from stimulation $\left(Z_{\text {Inh }}<0\right)$ to $Z_{\text {Inh }} \leq 33 \%$. With $\mathrm{H}_{2} \mathrm{~S}$ content growth $(100 \mathrm{mg} / \mathrm{L})$ the inhibitor contribution increases, but the inequality $Z_{\mathrm{Inh}}<Z_{\mathrm{f}}$ remains true. However, at $200 \mathrm{mg} / \mathrm{L} \mathrm{H} \mathrm{H}_{2} \mathrm{~S}$, 
$Z_{\text {Inh }}$ substantially decreases again. With a fourfold growth in the inhibitor concentration, the picture remains qualitatively the same. Addition of $\mathrm{CO}_{2}$ does not change the picture.

Let us consider some impedance spectroscopy data. The equivalent circuit shown in Fig. 1 [4] was used as a model of steel electrode impedance at $E_{\text {cor }}$. Addition of the inhibitors under study to the corrosive media results in an increase in the diameter of the semicircles in the Nyquist plots. This indicates that the total resistance of the system increases and the corrosion rate decreases. The diameters of the semicircles increase with an increase in experiment duration (Fig. 2), like in uninhibited solutions, which is caused by an increase in the protective efficiency of the surface coatings being formed in time. The charge transfer resistance in the anodic $\left(R_{1}\right)$ and cathodic $\left(R_{2}\right)$ reactions increases in the presence of inhibitors. This is particularly true for the anodic reaction. After exposure in NACE medium containing $100 \mathrm{mg} / \mathrm{L} \mathrm{H}_{2} \mathrm{~S}$ for $24 \mathrm{~h}$, the values of $R_{1}$ and $R_{2}$ are 1800 and $20 \mathrm{Ohm} \cdot \mathrm{cm}^{2}$, respectively, in the presence of $100 \mathrm{mg} / \mathrm{L}$ inhibitor I. The $R_{1} / R_{2}$ ratio amounts to 90 . This indicates that the corrosion process occurs under anodic control. In highly mineralized chloride media, $R_{1}=1750-1780 \mathrm{Ohm} \cdot \mathrm{cm}^{2}$ and $R_{2}$ decreases twofold, therefore $R_{1} / R_{2}=$ $175-178$. Hence, inhibitor I weakly hinders the cathodic process but nearly does not affect the corrosion rate because, as before, the corrosion process occurs under anodic control.

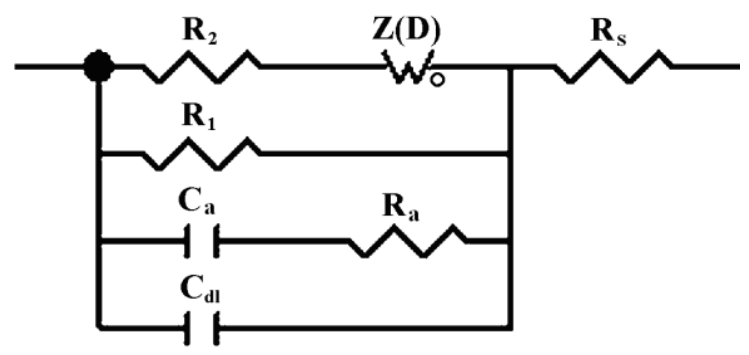

Fig. 1. Equivalent circuit of steel electrode at $E_{\text {cor. }}$

In the presence of inhibitor II in NACE medium, $R_{1}$ and $R_{2}$ are 380 and $20 \mathrm{Ohm} \cdot \mathrm{cm}^{2}$ and $R_{1} / R_{2}=19$ (other conditions being equal). Although this ratio is smaller than in the presence of inhibitor I, the corrosion process is still under anodic control.

Addition of the inhibitors to the solution causes a decrease in the double layer capacity $C_{\mathrm{d} l}$. In NACE solution, $C_{\mathrm{dl}}$ decreases from 50 to $10 \mu \mathrm{F} / \mathrm{cm}^{2}$ in the presence of $100 \mathrm{mg} / \mathrm{L}$ of inhibitor I $\left(C_{\mathrm{H}_{2} \mathrm{~S}}=100 \mathrm{mg} / \mathrm{L}\right)$. In the medium containing $50 \mathrm{~g} / \mathrm{L} \mathrm{NaCl}$, it changes from 150 to $20 \mu \mathrm{F} / \mathrm{cm}^{2}$.

The inhibitors under study show a bactericidal effect against SRB in the Postgate medium where bacteria grow under the most favorable conditions. Addition of $25 \mathrm{mg} / \mathrm{L}$ inhibitor I to Postgate medium suppresses their vital activity and decreases the concentration of biogenic $\mathrm{H}_{2} \mathrm{~S}$ from $300 \mathrm{mg} / \mathrm{L}$ to $200 \mathrm{mg} / \mathrm{L}$ (Fig. 3). A further four-fold growth in the inhibitor concentration decreases the $\mathrm{H}_{2} \mathrm{~S}$ content by an order of magnitude (to $30 \mathrm{mg} / \mathrm{L}$ ). Inhibitor II shows similar efficiency. The higher the inhibitor concentration, the more considerably inhibiting compositions I and II decrease the quantity of sulfatereducing bacteria in the Postgate medium (Fig. 4). 


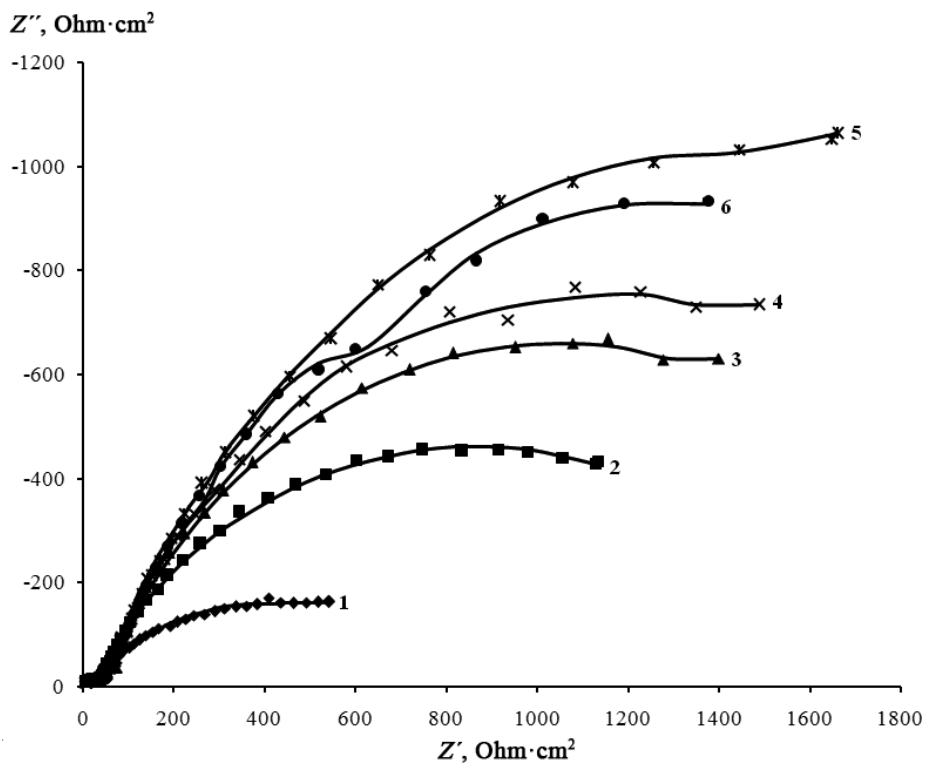

Fig. 2. Nyquist plot at $\mathrm{E}_{\text {cor }}$ in NACE medium saturated with $\mathrm{H}_{2} \mathrm{~S}(200 \mathrm{mg} / \mathrm{L})$ and $\mathrm{CO}_{2}(1 \mathrm{~atm})$ in the presence of inhibitor II (200 mg/L). Test duration, h: 1, 0.25; 2, 2; 3, 4; 4, 6; 5, 8; 6, 24. (The dots correspond to the experimental data, whereas the solid line shows data calculated from the equivalent circuit).

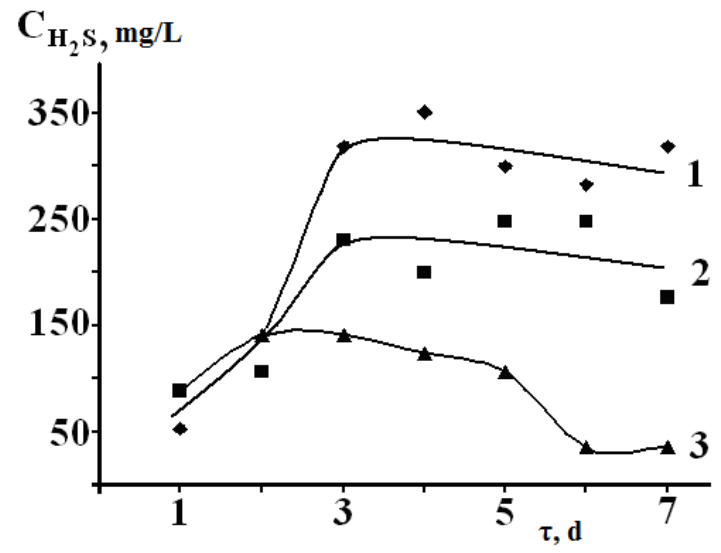

Fig. 3. Plot of $\mathrm{H}_{2} \mathrm{~S}$ concentration produced by SRB versus time $(\tau / \mathrm{d})$ of microorganism growth in the Postgate medium without an inhibitor (1) and with inhibitor I at concentrations of 25 (2) and $100 \mathrm{mg} / \mathrm{L} \mathrm{(3).}$

\section{Conclusions}

The inhibitors under study are versatile: they suppress the corrosion process both in the presence of hydrogen sulfide and in the presence of $\mathrm{H}_{2} \mathrm{~S}$ and $\mathrm{CO}_{2}$ together. In addition, they are efficient as bactericides.

Inhibitor I hinders the anodic reaction of steel more efficiently than inhibitor II. However, both are anodic inhibitors in the presence of which the charge transfer resistance of the anodic reaction is many times higher than that of the cathodic reaction.

The nature of the corrosive medium substantially affects how inhibitor protective efficiency changes in time. In NACE medium in all studied range of $\mathrm{H}_{2} \mathrm{~S}$ concentration the 
inhibitor adsorption is substantially faster than the formation of the film of corrosion products. In highly mineralized chloride media, an opposite picture is observed, so the film contribution to the total protective efficiency is larger than that of the inhibitor and essentially increases in time. The protective efficiency of "inhibitor/corrosion product film" system depends on hydrogen sulfide concentration.
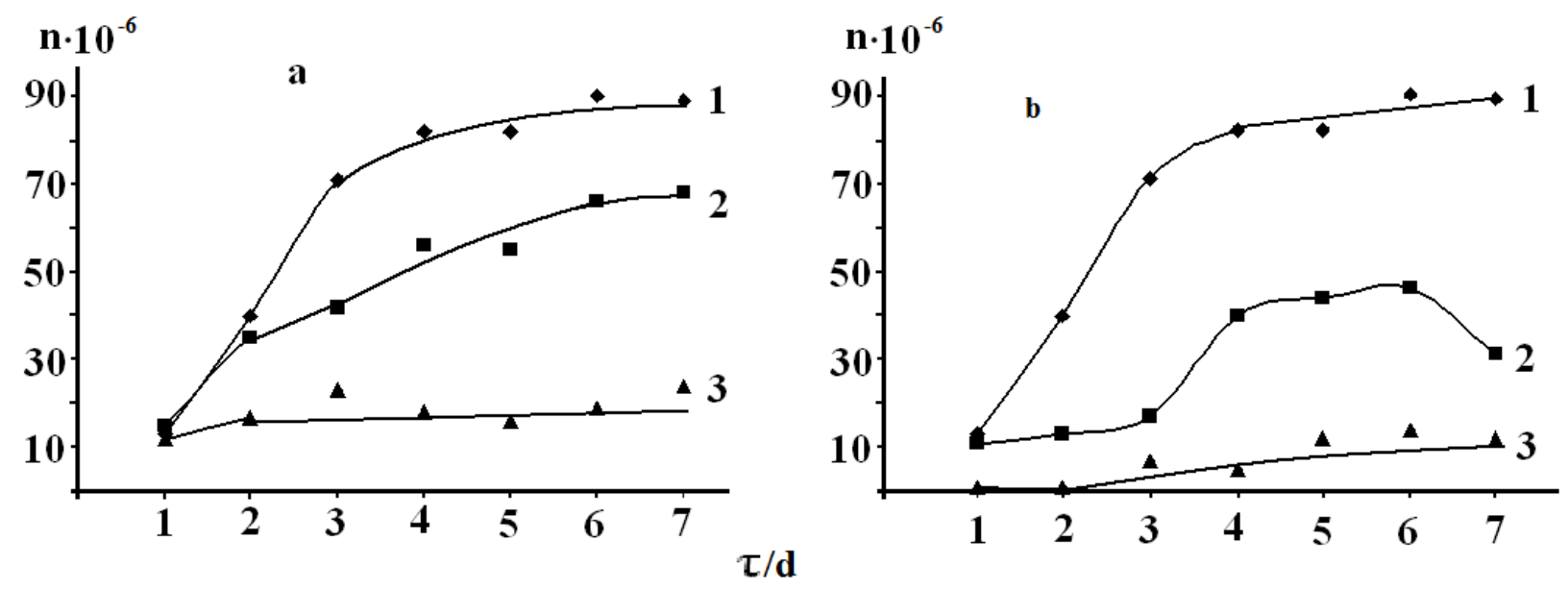

Fig. 4. SRB cell number $\left(\mathrm{n} / \mathrm{cm}^{3}\right)$ (ordinate) is a function of time ( $\tau /$ days) (abscissa) of microorganism growth in the Postgate medium without an inhibitor (1) and with inhibiting compositions I (a) and II (b) at concentration of 25 (2) and $100 \mathrm{mg} / \mathrm{L} \mathrm{(3).}$

\section{References}

1. M. A. Lucio-Garcia, J. G. Gonzalez-Rodriguez, M. Casales, L. Martinez, J. G. ChaconNava, M. A. Neri-Flores and A. Martinez-Villafañe, Corros. Sci., 2009, 51, 2380.

2. R. V. Kashkovskiy, Yu. I. Kuznetsov and L. P. Kazansky, Corros. Sci. 2012, 64, 126.

3. NACE MR0175, Sulfide Stress Cracking Resistant Metallic Materials for Oilfield Equipment, National Association of Corrosion Engineers, 1992.

4. L. E. Tsygankova, V. I. Vigdorovich, V. I. Kichigin and E. Kuznetsova, Surf. Interf. Anal., 2008, 40, 303.

5. V. I. Vigdorovich, L. E. Tsygankova and N. V. Shel, Surf. Interf. Anal., 2010, 42, 626.

6. N. G. Anufriev, E. E. Komarova and N. E. Smirnova, Korroz.: Mater. Zashch., 2004, 42 (in Russian).

7. V. I. Vigdorovich, L. E. Tsygankova, D. V. Balybin and V. I. Kichigin, J. Electroanal. Chem., 2012, 689, 117.

8. J. R. Postgate, The sulphate reducing bacteria, $2^{\text {nd }}$ ed., Cambridge University Press, Cambridge, 1984.

9. E. P. Rozanova, T. N. Nazina and A. S. Galushko, Microbiology (English translation), 1988, 57, 514.

10. A. Rose, Chemical Microbiology, Mir, Moscow, 1971 (translation from English). 